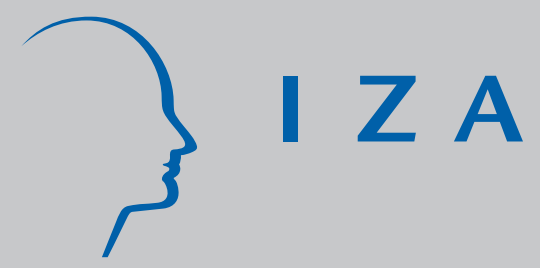

IZA DP No. 1342

Perspectives on the Early Retirement Decisions of Farming Couples

Minna Väre

Almas Heshmati

October 2004 


\title{
Perspectives on the Early Retirement Decisions of Farming Couples
}

\author{
Minna Väre \\ MTT Economic Research, \\ Agrifood Research Finland \\ Almas Heshmati \\ Seoul National University, \\ MTT Economic Research and IZA Bonn
}

Discussion Paper No. 1342

October 2004

\author{
IZA \\ P.O. Box 7240 \\ 53072 Bonn \\ Germany
}

Phone: +49-228-3894-0

Fax: +49-228-3894-180

Email: iza@iza.org

\begin{abstract}
Any opinions expressed here are those of the author(s) and not those of the institute. Research disseminated by IZA may include views on policy, but the institute itself takes no institutional policy positions.
\end{abstract}

The Institute for the Study of Labor (IZA) in Bonn is a local and virtual international research center and a place of communication between science, politics and business. IZA is an independent nonprofit company supported by Deutsche Post World Net. The center is associated with the University of Bonn and offers a stimulating research environment through its research networks, research support, and visitors and doctoral programs. IZA engages in (i) original and internationally competitive research in all fields of labor economics, (ii) development of policy concepts, and (iii) dissemination of research results and concepts to the interested public.

IZA Discussion Papers often represent preliminary work and are circulated to encourage discussion. Citation of such a paper should account for its provisional character. A revised version may be available directly from the author. 
IZA Discussion Paper No. 1342

October 2004

\section{ABSTRACT}

\section{Perspectives on the Early Retirement Decisions of Farming Couples}

In the past decade, the European agricultural sector has undergone rapid structural change. Part of that change is manifested in extended early retirement plans. As pensions play a crucial role in determining the characteristics the change, it is important to establish the factors determining the exit from farming among elderly farmers. This study analyses the choice of pension scheme of farmers. The focus is on the effects of farm and off-farm incomes and various offered economic incentives on farmers' retirement decisions. The results provide valuable information concerning evaluation of existing programmes and the design of future retirement systems and policies.

JEL Classification: J26, Q12, C25

Keywords: early retirement, farming couple, bivariate probit

Corresponding author:

Minna Väre

MTT Economic Research

Luutnantintie 13

00410 Helsinki

Finland

Email: minna.vare@mtt.fi 


\section{INTRODUCTION}

During the past ten years, the Finnish agricultural sector has undergone a rapid structural change. This has been manifested in significant changes in both the number and size of farms. The number of farms has decreased from 113,109 in 1990 to 63,179 in 2003 and the average farm size has increased from 17.7 hectares to 31.0 hectares during the same period (Appendix 1 and Mela, 2004). At the same time, both farm income and its share of the farm family's total income have been decreasing. In the year 2000, farm income contributed $39 \%$ of total farm family income. Wages and salaries from off-farm work and other entrepreneurial activities amounted to $35 \%$ of total farm family income. In 1990, the corresponding shares were 51\% and 29\% (Statistics Finland, 2000). As well as having an ever increasing importance for farm households, off-farm employment has also an increasing effect on farm household decisions. One of the most important decisions during the farmer's career is when the farmer is going to retire and what happens to the farm after that retirement. Thus, as off-farm work is becoming more and more common practice and a significant complement to farm incomes, it is crucial to know how off-farm income affects farmers' retirement decisions.

In previous studies, part-time farming has been found to both stabilise the farm household income and also accelerate farm exits by reducing transaction costs for those seeking to leave agriculture (Goetz and Debertin, 2001). Because off-farm income stabilises the farm household (Kimhi and Bollman, 1999), for example, in cases of agricultural income variability and policy changes (Mishra and Goodwin, 1997), it can be seen as a stable long-run combination with farming rather than a step in the way out of agriculture (Kimhi, 2000, p. 46). Part-time farming has, however, been found to promote the re-structuring of the farming sector (Pfeffer, 1989; Weiss, 1999). Parttime farmers have lower expectations for continuing farming both in the short- and long-run compared to full-time farmers (Pfeffer, 1989). Likewise, part-time farms have lower probabilities of survival and growth compared to full-time farms (Weiss, 1999). Also, on part-time farms, the probability of succession is found to be lower and the probability of other farm exits higher (Stiglbauer and Weiss, 2000). A farm may also be transferred to a successor earlier, if a farmer has off-farm work. This is a method which parents use to maximise family welfare (Kimhi, 1994). In summary, research indicates that off-farm income is financially important in smoothing the household income variability but it also negatively affects the productivity and profitability of farms, thereby reducing their survival rate.

In studying farmers' exit behaviour in different countries, institutional differences, financial incentives and constraints are found to matter (Kimhi and Bollman 1999). In the European Union, farmers' early retirement provisions are carried out according to the Rural Development Regulation of the Common Agricultural Policy (CAP). This regulation aims to secure the income of retiring farmers and to improve the livelihood of farms with continuous operation. Because the early retirement system is voluntary, the procedures and practices of such measures applied in the member countries vary a lot. For example, in Ireland a successor does not have to purchase the farm from her/his parents or siblings but $\mathrm{s} /$ he has to provide a living for the previous generation from the farm income. This kind of commitment to financial responsibility to former 
owners is not the case, for example, in Finland. When comparing intergenerational transfers in different countries, Errington and Lobley (2002) came to the conclusion that the managerial responsibility for a farm is handed over earlier in France than in England. This is because France, unlike England, applies the early retirement and installation elements of the Rural Development Regulation of the CAP. More details about retirement programmes and its practices in the context of EU-countries can be found for example in Blanc and Perrier-Cornet (1993).

As types of occupational choices among elderly farmers play a crucial role in determining the characteristics of structural change in agriculture, it is important to establish what are the factors determining the type of exit from farming especially among elderly part-time farmers. Furthermore, it is important to find out how public policies, such as early retirement programmes foster these choices. By elderly farmers, we mean farmers who are sufficiently old to be eligible to have the option to voluntarily exit from farming using an offered pension benefit scheme. New information on the effects of off-farm work on the farming couple's retirement behaviour is especially needed now, since the large so-called 'baby-boom generation' born in the late 1940s and early 1950 s is approaching retirement age.

This study analyses the choice of pension scheme of elderly farmers. The choice is studied by the use of qualitative methods. In the analysis, the farming couple's exit decisions are grouped into those who choose a farmers' early retirement system and those selecting other pension schemes. Exits by the farmers' early retirement system are further characterised by two discrete occupational choices: exit and transfer of the farm to a new entrant, and exit and the closing down of the farm. Exits by other pension schemes are divided into involuntary exits (disability pension, etc.), old-age and other forms of pension, and the continuation of farming.

The contribution of this paper to existing literature is that it analyses the impact of offfarm income on a farming couple's exit decisions. The farm transfer to a new entrant (farm succession) and farm closure are modelled as separate, mutually exclusive decisions. Also, the farm and off-farm income and other economic incentives to promote or alternatively to discourage their retirement are considered in the analysis. Here, by economic incentive, we mean the amount of income loss defined as the difference between agricultural and forestry incomes minus expected pension receipts.

The results provide insights into how farmers' off-farm income affects the type of exit decisions made by elderly farmers. These results provide valuable information concerning evaluation of programmes employed in the past, the existing programmes and the design of future retirement systems and policies that are financially viable and aim at improving desirable structural adjustment to the agricultural sector.

The rest of the paper is organised as follows: in the following section, we introduce an early retirement plan in the context of the Finnish and European agriculture and its evolution over time. The data are described in Section 3. The models used in the analysis are outlined in Section 4. In Section 5, the results are presented and discussed. The final Section 6 concludes. 


\section{EARLY RETIREMENT POLICY}

In Finland, farmers' early retirement programmes were first introduced in 1974. The aim of these programmes was to maintain the livelihood of family farms continuing production and thus improving the competitiveness in the agricultural sector. Since then, there have been several programmes of short duration that included: (i) change of generation pension, (ii) farm closure compensation and (iii) early retirement aid to farmers. The common lower age limit for all these programmes has been 55 years. This means, that farmers, aged between 55 and 64, who either ceased production of their farms by selling or leasing agricultural resources to neighbouring farms or transferred their farm to new entrants, received retirement benefits that they would have normally received at the age of 65 . Retirement was also possible by reforestation of the land or by lay-land agreement. The early retirement benefits are farmer specific and they depend on the level of pension insurance the farmers have purchased over their active farming years (Mela, 2003). Since 1995, Finland has carried out farmers' early retirement programmes within the EU framework for these programmes.

During the last 30 years, over 67,000 farms have benefited from the farmers' early retirement programmes in Finland (Appendix 1). At the same time, number of farms and farm population insured by Farmers' Social Insurance Institution (Mela) has decreased and average farm size increased. In practice, purchasing pension insurance from Mela has been obligatory for all farmers. It is also a pre-condition for applying for a farmer's early retirement pension. The number of farmers exiting farming by means of the farmers' early retirement scheme per year was highest in the late 1980s and early 1990s (Appendix 2). In addition to making easy the survival and the transfer of farms financially possible, the programmes served as an active labour market measure during a period of increased unemployment. Switching job by farmers is a difficult task due to the mismatch of skills and low mobility of farmers as a labour force. During recent years, the number of farms applying to the programme has been decreasing.

In the European Union, regulations on enhancing farms to give up operation of farms were first introduced in 1988. Up to 1992, in practice, only Germany applied a farmers' early retirement scheme based on these regulations. According to the scheme, a farmer, aged 58-64 years, received early retirement pension if s/he stopped cultivating her/his land, reforested it or sold it. In 1992, new regulations were introduced for farmers' early retirement systems in the EU. The aim of these regulations was both to secure the income of retiring farmers and to help replace them by other farmers more able to improve the livelihood of continuing farms. The age limit for retiring farmers was lowered to 55 years. Being voluntary also, this system was applied in less than ten EU member states. In 1999, this second wave of regulation was replaced by the Community aid scheme for early retirement from farming included in the Rural Development Regulation (EC Council Regulation 1257/1999). This aid scheme includes no more restrictions concerning full-time farming as was a pre-condition in the earlier schemes (HE, 1992:194; 1994:162; and 1999:131). 


\section{THE DATA}

\subsection{Data description}

Data on farmers' exit decisions and retirement choices were obtained from the Finnish Farmers' Social Insurance Institution (Mela) and complemented by farmer income data and information on farmers' household characteristics from Statistics Finland. The data are a good representation of the population of elderly farmers in Finland, since the purchasing of pension insurance from Mela is obligatory for all farmers.

The data consists of a sample of 963 farms. The sample is a random selection of all farmers born between 1929 and 1943 and stratified after the farmer's age corresponding to the share of all farmers at every age. All the farmers in the data set were active farmers in 1993. The data set forms a balanced panel prior to the retirement and runs from the year 1993 to the year 1998. There is no information available on income post-retirement. All farmers in the data set were eligible to the farmers' early retirement scheme during the study period according to his/her age. The oldest farmer in the data was 64 years old in 1993 and youngest one was 55 years old in the final year 1998.

The share of farmers with a spouse is $47 \%$ in the sample. The share of couples choosing farmers' early retirement pension is much higher at $71 \%$. There are 456 farms operated by couples. In the study, the older member of the farming couple is defined as the farmer and the younger as the spouse, since eligibility to the early retirement scheme is determined by the age of the older person in the couple.

In this study, farms are divided according to the choice of pension scheme of the farmer and his/her spouse to different groups (Figure 1). The choice of pension scheme, farm transfer and continued farming are the dependent variables. First, farms are divided into two groups according to whether they choose the farmers' early retirement system or not. Exits by the farmers' early retirement system are further characterised by two discrete occupational choices: exit and transfer of the farm to a new entrant, or exit and closing down the farm. Those farms not choosing the farmers' early retirement scheme are further divided into those continuing to farm, and those using other pension schemes than pre-retirement. There are no farms where both the farmer and spouse exit involuntarily (e.g. due to death, disability pension, etc.). Out of the 963 sample farms, one fifth or 194 farms chose to retire within the frame of farmers' early retirement pension. Out of these farms, more than one half is transferred to a new entrant. More than half of those farms not choosing the farmers' early retirement scheme, 769 in total, continue farming and almost half of them chooses old-age or other pension systems.

Figure 1.

Descriptive statistics of the data characterising different groups of farms eligible to pension schemes, farm transfers and continuous operation are presented in Table 1. When comparing the differences between different groups, it seems that those farmers and spouses choosing the farmers' early retirement system are older and have smaller 
dispersion in the couple's ages than those not choosing the farmers' early retirement system. Farms choosing the early retirement system also seem to more often be operated by a couple. Farmers choosing the early retirement system also have more children. On average, the oldest child is also older on these retiring farms than on other farms. Farms choosing an early retirement pension are also to some extent larger than other farms in the sample measured by the size of arable land and forest area. Farms choosing the early retirement system are also more often located in southern parts of the country and are specialised in other production activities than livestock. Because of having higher agricultural income than other farms, the income loss is also bigger (as well as its dispersion among farms) when retiring by choosing the farmers' early retirement system. These farms also have lower off-farm income (and smaller deviation among the farms) than other farms in the sample.

Table 1.

\subsection{The variable definitions}

The explanatory variables included in the analysis were defined after the earlier studies on labour force transition and on farmers' exit decisions. According to Kerkhofs et al. (1999), 'financial incentives are the most important factors determining the choice to apply for an early retirement scheme'. Kerkhofs et al. (1999) have also found that when making retirement decision, income streams in alternative exit routes are compared and that different alternative exit routes serve as substitutes. Also, Pietola et al. (2003) found that higher retirement benefits increase the probability of both farm succession and farm closure.

In this study, the economic incentive to retire is measured as an income loss of farmer and spouse when retiring using the farmers' early retirement schemes. The income loss is measured as the difference between agricultural and forestry incomes before retirement and the expected pension benefit when retired. Income loss is measured annually for both farmer and spouse individually and the aggregate for the farm. The two retirement incomes are complements and in pooled form satisfy better an expected retirement income level. In pension studies, replacement ratios (ratio between expected pension and income before retiring) are often used when modelling withdrawal from the labour market because it is believed that it is the ratio of the expected pension benefit and expected wages that matters rather than the income levels (Hakola, 2003). In this study, however, income loss when retiring is used. The ratio accounts for individual levels of income but ignores the between farm differences in levels, while income loss quantifies the individual losses but ignores the income levels. The income loss is on the average $38.2 \%$ of agricultural income with very large dispersion. It is much higher for farm transfer than those continued farming.

It has been found that on part-time farms, the probability of succession is lower and probability of other forms of farm exits is higher (Stiglbauer and Weiss, 2000). As such, in this study, off-farm income is used as an explanatory variable in the analysis to reflect higher propensity to exit farming. The sample average is $43 \%$ of agricultural income with large dispersion. It is higher for groups of farms with continued operation compared to those transferring the farm. 
There is evidence that the probability of transferring the farm to a new entrant first increases with the farmer's age and then beyond a certain age limit it decreases (Kimhi and Bollman, 1999; Stiglbauer and Weiss, 2000; Kimhi and Nachalieli, 2001). This is especially the case in family successions. On the contrary, the probability of other forms of exits is found to increase with a farmer's age (Kimhi, 1994; Stiglbauer and Weiss, 2000; Kimhi and Nachlieli, 2001; Pietola et al., 2003). In this study, both the age of farmer and spouse and the number of years a farmer has been farming are included in the analysis as explanatory variables. The farmer is in average 5 years older than the spouse. The age at transfer is higher than at continuity of operation. The same applies to the years of farming.

It has also been found that the larger the farm, the more likely the succession is and less likely the farm closure (Gasson et al., 1988; Stiglbauer and Weiss, 2000; Kimhi and Nachlieli, 2001; Glauben et al., 2002; Hennessy, 2002; Pietola et al., 2003). To capture the effects of size, in this study, the size of farm is measured by the size of farmland and forestland both measured in hectares. We do not see much difference in the size of forest land. However, the size of arable land differs among the two groups and it is $53 \%$ higher for the transfer category compared to farms with continued farming.

Except that the farm size increases succession probability, the effect can also be contrary. Potter and Lobley (1992) have found that farmers without a successor do not have the motivation to expand their farms but tend to reduce their working hours (shadow effect). The number of children living on a farm on the other hand, has been found to increase succession probability (Stiglbauer and Weiss, 2000; Glauben et al., 2002). In this study, existence and number of children and the age of the oldest child are included as explanatory variables in the analysis. The average number of children per farm is 2.3 and the age of the oldest child is on average 25.7 years. These numbers are somewhat higher among the transfer farms.

Also the existence of a spouse in the household has been used as an explanatory variable in earlier studies. Pietola et al. (2003) suggest that a farmer is expected to retire earlier if $\mathrm{s} / \mathrm{he}$ has a spouse. In this study, the existence of a spouse is included as a dummy variable in the analysis.

The farm's regional location and production line may also significantly influence the timing of a farmer's retirement. In this study, farms are divided according to their production line into livestock farms (dairy, cattle, pig, poultry, sheep, goat and horse farms) and other mainly crop farms (crop and other plant production farms). In addition, farms are divided according to their location to those located in Northern and those located in Southern parts of the country. The division is made according to the EU-subsidy areas in Finland so that northern area includes areas classified as C2, C3 and $\mathrm{C} 4$.

In addition, in order to capture the effect of subsidies, a variable labelled as 'Sshare' is formed by multiplying the area subsidy for barley per hectare by the farm's land area and dividing the sum by agricultural income per farm. The new variable is included in 
the analysis simply because farms in northern and southern parts of the country differ by land and forest area from each other. The share is quite small and the value is lower for transfer farms. Interaction variables such as 'South-land' and 'North-forest' are obtained by multiplying land area and forest area by dummy variables indicating north and south, with south being opposite to north. Variable 'Trend' is defined so, that in the year 1993 it gets the value 1 and in the final year 1998 it gets the value 6 .

Correlation between dependent and independent variables is shown at Table 2. As expected, pension is positively correlated $(0.708)$ with transfer of farm and negatively correlated (-0.412) with continuity of operation. None of the dependent and independent variables is highly correlated with each other. The correlation coefficients between the two sets of variables lie in the interval between -0.346 and +0.362 . Among the explanatory variables, we find that agricultural income of the farm (Xagrincome) is correlated with land (0.447) and with the income loss of the couple when retired (Xreplace) with a correlation coefficient of 0.944 . This is reasonable since income loss is higher the bigger the agricultural income is, though the expected pension depends also on agricultural income. Remaining correlation coefficients are quite low and in the interval between -0.258 and 0.303 . With the exception of income and income loss variables, there is no indication of multicollinearity being a major problem.

Table 2.

\section{THE MODELS AND METHODS}

The issues studied here deal with farmers' exit decisions and their choice of exit channel. Earlier studies on farmers' exit decisions have used e.g. logit (Kimhi, 2000; Stiglbauer and Weiss, 2000), probit (Kimhi and Bollman, 1999; Kimhi and Nachlieli, 2001) or bivariate probit models (Glauben et al., 2002). Both probit and logit models can handle situations with single as well as multiple ordered or non-ordered choices and are estimated by maximum likelihood method. They assume, however, different distributions in the error term, normal and logistic, respectively. The choice is made based on how well each describes variations in the data.

In this study, five probit models including three univariate and two bivariate probit models are estimated. The univariate probit models are used to analyse issues of: (i) a farmers choice of early retirement versus no early retirement, (ii) the transfer or close down of the farm given early retirement chosen, and (iii) continued farming or old-age pension given no early retirement chosen. The last two choices are conditional, while the first one is not. Since there are no farms exiting involuntarily, the non-early retirement choice is also modelled with binary probit model. However, non-early retirement exit alternatives are beyond the scope of this paper. The two bivariate probit models are formulated to analyse: (iv) early retirement and farm transfer to the next generation, and (v) no early retirement system and continued farming. ${ }^{1}$

For a complete schematic picture of the set of exit choices see Figure 1. The bivariate probit model has the advantage that it accounts for selectivity in analysis of two simultaneous decisions. The choice of univariate or bivariate probit model is testable. A pri- 
ori, we find it appropriate and beneficial to use bivariate models for analysis of early retirement and follow up of sample farms.

\subsection{Univariate probit analysis}

In the probit model, a discrete choice among two possibilities will be described by the latent dependent variable $y$. Probit model follows normal distribution (Maddala 1983):

$$
y_{i}^{*}=\alpha+\beta^{\prime} x_{i}+\varepsilon_{i}
$$

where the residual term is normally distributed as $\varepsilon_{i} \sim\left(0, \sigma^{2}\right)$. In the model, observed dependent variable $y$ will get two values:

$$
\begin{array}{ll}
y=1 & \text { if } y_{i}^{*}>0 \\
y=0 & \text { otherwise }
\end{array}
$$

In the first case, (i) y gets the value 1 if the farmer is retiring by farmers' early retirement pension and zero if not. In the second case, (ii) $y=1$ if the farm is transferred to successor and $y=0$ if the farm is closed given the early retirement pension being chosen. In the third case, (iii) of continued farming $y=1$ if the farming couple continues to operate and $y=0$ if the farming couple retires with an old age or some other form of pensions given no early retirement pension is chosen. Modelling will be done separately for these three choices.

The analysis probability of $y=1$ depends on a vector of independent variables labelled as $x$. The probability of $P(y=1)$ increases with $\beta^{\prime} x$. Thus, assuming that $\sigma^{2}=1$, we get:

$$
\begin{aligned}
& P\left(y_{i}=1\right)=\Phi\left(\alpha+\beta x_{i}\right) \\
& P\left(y_{i}=1\right)=1-\Phi\left(\alpha+\beta x_{i}\right)
\end{aligned}
$$

where $\Phi=$ cumulative distribution function of the normal distribution with normalised variance.

\subsection{Bivariate probit analysis}

Next, two bivariate probit models are estimated to analyse the dependency of two possibly interdependent alternative choices. This method is used in evaluation of the effects of programme participation to isolate the programme effects. The priors here are that intergenerational transformation of farms might affect the retirement decision, and a continued farming excluding retirement options.

The economic models have two choice variables and decision rules to be estimated. The first choice variable $\left(y_{1}\right)$ is the farmer statement whether $\mathrm{s} / \mathrm{he}$ is or $\mathrm{s} / \mathrm{he}$ is not choosing farmers early retirement system. The second choice variable $\left(y_{2}\right)$ is in the first model (iv) transfer of the farm to a new entrant or close it down, and in the second model (v) continued farming over choosing other pension scheme. The model has 
a recursive structure so that the farmer is hypothesised to first choose the farmers' early retirement system or not, and then in the first model transferring the farm to a new entrant and in the second model continuing to farm. Therefore, choosing early retirement or not $\left(y_{1}\right)$ enters as an endogenous explanatory variable in the equations for the farm transfer and continuing to farm $\left(y_{2}\right)$. The system of two equations is written as:

$$
\begin{aligned}
& y_{i}^{1^{*}}=\beta^{1} x_{i}^{1}+\varepsilon_{i}^{1} \\
& y_{i}^{2^{*}}=\beta^{2} x_{i}^{2}+\gamma y_{i}^{2^{*}}+\varepsilon_{i}^{2}
\end{aligned}
$$

where the superscript $i$ refers to farmer $i$ and an asterisk $\left(^{*}\right)$ refers to the uncensored latent form, which is unobserved. The matrices $x^{1}$ and $x^{2}$ include exogenous instruments, such as farmer and farm characteristics. The unknown parameters to be estimated, as denoted by $\beta^{l}$ and $\beta^{2}$ and the error $\varepsilon=\left(\varepsilon^{l}, \varepsilon^{2}\right)$, are normally distributed with mean zero and the variance covariance matrix $\Sigma$. That is to say $\varepsilon \sim N(0, \Sigma)$. The parameter $\gamma$ indicates the effects of the first decision of early retirement on the second decision of transfer or continued farming. It is used to test the choice of univariate or bivariate formulation of the choices. As standard in probit models, the model parameters are identified by normalising the variance of the errors at 1 . Under this normalisation, the variance covariance matrix takes the form:

$$
\Sigma=\left[\begin{array}{ll}
1 & \rho \\
\rho & 1
\end{array}\right]
$$

where $\rho=\operatorname{Cov}\left(\varepsilon^{1}, \varepsilon^{2}\right)$. The latent form decision variables are censored such that:

$$
\begin{array}{ll}
y_{i}^{1}=1 & \text { if } y_{i}^{1^{*}}>0, \text { and } 0 \text { otherwise } \\
y_{i}^{2}=1 & \text { if } y_{i}^{2^{*}}>0, \text { and } 0 \text { otherwise }
\end{array}
$$

In other words, in the first model, if the farmers' early retirement pension is chosen, the binary indicator measuring the choice of the farmers' early retirement system $\left(y^{l}\right)$ equals to one and otherwise to zero. Similarly, if the farm is transferred to a successor the choice variable $\left(y^{2}\right)$ takes value one and, if it is closed, it takes the value zero.

The parameters in the two, possibly correlated, censored choice equations are estimated by a binomial probit model using the standard maximum likelihood method. The structure of the choice probabilities and the log-likelihood function can be found, for example, in Greene (1998).

\section{THE RESULTS}

\subsection{Model specification, estimation and performance}

An analysis of farmers' decisions in response to the proposed pre-retirement pension plans, as described previously, is first made by three different univariate probit models of retirement, transfer and continuity and then by two bivariate probit models of early 
retirement-transfer and non-early retirement-continuous operation. Parameter estimates for three univariate separate probit models are shown in Table 3 and those of bivariate models in Table 5. The predicted probabilities of the two sets of models are reported in Tables 4 and 6, respectively.

Variables included in the analysis are selected with reference to the practice by the existing literature, according to the data availability and the a priori expectations of the factor influences. Thus, for example, income loss when retiring by the early retirement scheme is included in the probit model of choosing the early retirement system but not in the probit model of continuing to farm given no early retirement system is chosen. In addition, some limited interaction terms of variables will be formed to capture their joint effect on farmers' decisions. Statistical significance of the estimated individual and sets of coefficients is tested by t-test and likelihood ratio test, respectively.

The data are a balanced panel data set. Estimated univariate probit and bivariate probit models are mainly based on cross-sectional information in the choice variable but year-to-year changes in the variables explaining the choices are accounted for. This means, in the estimation that no attention is paid to which year farming couple retires, but on whether they retire in the first place and in what way. Farms in the data set differ from each other by land and forest area, location and production line. Thus, they form a heterogeneous group. The heterogeneity is accounted for by using relevant covariates.

Results suggest that the estimated probit model coefficients are jointly statistically significant at any conventional levels of significance, as measured by the likelihood ratio test. Here the test is based on log likelihood obtained from the unrestricted models specified as reported on Tables 3 and 5 and those restricted where all or subsets of the slope coefficients are assumed to be zero. The test results rejected the restricted models in favour of the unrestricted model specifications.

The three probit models correctly predict $19.1 \%$ - 97.1\% of all observations (see Table 4). The Table shows that $20.1 \%$ of the farmers choose pre-retirement pension. The pension model is performing worse compared to the transfer and continuous operation models. Whereas $97.1 \%$ of non-pension and $19.1 \%$ of pension cases are classified correctly, the percentages of incorrect cases are $2.9 \%$ and $80.9 \%$, respectively.

Given that the pension is chosen, a total of $55.7 \%$ selected intergenerational transfer. Unlike the pension model described above, the transfer model is performing better by correct prediction rates of $69.2 \%$ non-transfer and $83.0 \%$ of transfer cases. The relative performance in prediction of transfer versus non-transfer is thereby higher. The percentage of incorrect predictions is $30.8 \%$ and $17.0 \%$.

For farmers choosing not to pre-retire, $50.3 \%$ of the farmers choose to continue operation of their farms, while other gradually select old-age pensions. The relative high performance of the model suggests that the model specification is adequate in explaining the variations in propensity to continue operation of the farms. The percentage of 
correctly predicted old-age pensions and continued operations are $88.0 \%$ and $78.3 \%$, while the remaining $12.0 \%$ and $22.7 \%$ are incorrectly predicted.

The estimated bivariate model for choosing early retirement and transferring the farm to a new entrant $(20.1 \%)$ given the early retirement chosen overestimates the probability of not transferring the farm to a new entrant (79.9\%) and underestimates the probability of transferring (11.2\%) or closing the farm down (Table 6). The estimated bivariate model for not choosing the farmers' early retirement system and continuing to farm underestimates the probability of not continue farming $(20.1 \%)$. It also underestimates the probability of continued farming (40.2\%). The observed and predicted probabilities of different stages are given in Table 6.

It is to be noted that in some cases the low correct prediction performance of such models is not an exception. Unlike in a production function with strong link between output produced and inputs used, there is no such one to one strong link between the choice of retirement and determinants of the choice. The researchers' access to and ability to identify relevance covariates is crucial to the specification and performance of the models. Given the rich Mela data with its high quality used in current study we find the model specification and performance satisfactory in the evaluation of early retirement schemes in Finland.

\subsection{Univariate probit results}

\section{A. Early retirement}

The parameter estimates of the early retirement model (Model 1 on Table 3) are with the exception of the barley subsidy share of farm income, the farmer's age and forest land significantly different from zero at the less than 5\% level of significance. The forest area and the farmer's age are weakly significant. One of the most significant factors affecting the farmers' choice of early retirement pension is the age of the spouse. The older the spouse, the higher the probability of farm transfer is to a successor or closing down the farm by selecting early retirement pension. To the contrary, a high age of farmer decreases the probability of early retirement. This implies that the optimality of early retirement age is a decreasing function of the age of the farmer but an increasing function of the age of the spouse. The degree of inoptimality might be due to the profitability of a farm, good health condition or absent of transfer possibilities, non-monetary valuation of a farm and employment opportunities. The negative association between early retirement and age of the farmer is consistent with earlier findings by Kimhi and Bollman (1999), Stiglbauer and Weiss (2000), Kimhi and Nachalieli (2001) and Pietola et al. (2003). These found that the probability of transferring farm to a new entrant increases first by the farmer's age but the effect reverses after a certain age.

Among other factors affecting positively the probability of selection of an early retirement pension are: the length of time that the farmer has been operating the farm, the number of children as a proxy for potential successors, as well as the size of land. The size of arable land is a pre-condition for farm transfer, investment opportunities, expansion, survival and profitability of farm. The loss of income following pre- 
retirement is unexpectedly positive. This might be due to the fact that farmers owning productive and profitable farms select early retirement with a higher probability to take advantage of the generous retirement offers as a measure to an advanced intergenerational transfer of the farm.

Unlike arable land, forest land is negatively correlated with the probability of early retirement. The same is true with farms located in the North. Farms in the North are very likely small and with limited potential to develop or being profitable to be transferred to successors. Although, the interaction of forest land and a northern location is found to be positively related to the probability of early retirement, while interaction of arable land and a southern location negatively affecting the probability of early retirement. An inclusion of these interaction effects is highly motivated but the estimated effects are unexpected, the reason of which is not known to us.

The probability of early retirement decreases if the farm is a livestock farm. These farms are more capital and labour intensive, a transfer of which requires higher skill and heavy investment resources. The size of land is another constraint on expansion possibilities at such farms. Income loss when choosing an early retirement pension measured as a difference between farm income and expected pension payments increases the probability to choose an early retirement pension. In line with earlier research, we expected a negative relationship. As a matter of sensitivity analysis, we estimated the same model specification but by excluding the income loss variable. The exclusion of income loss did not have any significant effect on the performance of the model in terms of correctly predicted probabilities and did not affect the remaining coefficients concerning changed signs. ${ }^{2}$ Overall farm income, off-farm income and barley subsidy as shares of farm income, each decreases the probability of early retirement. Farm income bears an influence also on the level of the farmer's pension when retiring. The trend in frequency of early retirement is negative reflecting a positive response by the farmer at the early stage of its introduction.

In summary, our result is in agreement with earlier findings that after first increasing, the probability of retiring by the farmer's early retirement scheme decreases by the farmer's age. The larger the farm and the longer period the farmer has been farming, the more likely early retirement is. Positive associations are a reflection of the desire to minimise income losses following early retirement and to facilitate the transfer of the farm to the next generation. Early retirement is less likely in the northern parts of country and on livestock farms.

\section{B. Intergenerational transfer of farms}

The parameter estimates for farm transfer model are with the exception of the farmer's age, years of farming and livestock as a production line significantly different from zero at the less than 5\% level of significance (Model 2 on Table 3). When choosing the farmers' early retirement pension, agricultural and forest land are found to be the most significant factors increasing the probability to transfer the farm to a successor. The result is in agreement with earlier findings, of among others, Gasson et al. (1988), Stiglbauer and Weiss (2000), and Kimhi and Nachlieli (2001) who found that the larger the farm, the more likely succession and the less likely farm closure is. 
The older the oldest child is and the more children the farming couple has, the more likely a farm succession is to take place. The positive relation between succession and farm children is obvious. Without a potential successor, a succession is hardly going to take place, even though an early retirement system does not make any difference between family and non-family successors. Also, Stiglbauer and Weiss (2000) and Glauben et al. (2002) have found that the number of children living on a farm increases the succession probability.

Unlike the probability of choosing an early retirement pension, the farm succession probability increases with the increasing age of the farmer and decreases by the increasing age of the spouse. This result is not expected. Succession probability also increases the longer the farmer has been farming. Unlike choosing an early retirement pension, the probability of farm succession is more likely if the farm is a livestock farm. This may be due to more intensive livestock production and thus better livelihood and employment possibilities compared to other non-livestock farms.

The most significant factor decreasing the probability of farm succession among farmers choosing an early retirement pension is the farm income. Succession probability also gets smaller the bigger the share of barley subsidy of farm income is. Off-farm income, on the other hand, increases the farm succession probability. This contradicts to the earlier findings of Stiglbauer and Weiss (2000) that part-time farming decreases the succession probability and increases the probability of other types of farm exits. One explanation for the significant contribution on succession may be past revenue shocks. Off-farm income has been earlier found to stabilise farm household income in case of income variability (Kimhi and Bollman, 1999; Mishra and Goodwin, 1997)

A northern location decreases the probability of transferring the farm to a new entrant. In other words, besides that the probability of choosing an early retirement pension being smaller in northern parts of the country, those farmers choosing retirement will more likely close down the farm. The probability of farm succession decreases over time. This is consistent with the general development of the structure of farming. The same is true when looking at the probability of choosing farmers' early retirement pensions.

In summary, similar to previous studies, the larger the farm and the older children of the farming couple, the more likely a farm succession is. In northern parts of the country, succession is less likely and farmers choosing early retirement tend more often to sell than close the farm operation.

\section{Continued operation of farms}

The parameter estimates for the model of farms continuing operation differ significantly from zero at the less than 5\% level of significance. The exceptions are the number of children, age of the oldest child, agricultural land, dummy variable for livestock farm and share of barley subsidy of farm income (Model 3 on Table 3). 
Where the farmers' early retirement pension is not chosen, the most significant factors determining whether the farmer or the spouse continue to farm or not, are the age of the farmer and the spouse (Model 3 on Table 3). The older the farming couple is, and the longer the farmer has been farming, the more likely the farming couple will stop farming. On the other hand, the existence of a spouse increases the probability of continuing to farm. This is because in this study, the older of the spouses regardless of gender is defined as a farmer.

An increase in the age of the oldest child decreases the probability of continuing to farm. This is due to the increased propensity for farm successions in cases of not selecting farmers' early retirement schemes. Also, in northern parts of the country, farmers are less likely to continue farming. This is consistent with the earlier findings, since both choosing the farmers' early retirement pension and having farm succession were less likely in northern parts of the country. These findings suggest that farming is less likely to be continued in the northern part of the country.

The larger the farm measured by agricultural land and forest area, the more likely the farming couple will continue to farm. Also, the bigger the agricultural and off-farm income, the less likely they will retire. The probability of continuing to farm is a positive function of the number of children, if the farm is one of livestock. The probability of continuing to farm increases according to the share of the barley subsidy of farm income, as well as over time.

In summary, the older the farming couple are, and the longer the farmer has been farming the more likely they will choose some pension scheme. Also, the increasing age of the possible successor increases retirement probability. In northern parts of the country, farmers are less likely to continue farming.

Table 3.

Table 4.

\subsection{Bivariate probit results}

Next, two bivariate probit models are estimated in order to analyse the dependency of choosing the farmers' early retirement system and transferring the farm to the next generation and the dependency of not choosing the farmers' early retirement system and continuing to farm. Results of these two bivariate probit models are shown in $\mathrm{Ta}$ ble 5 and their predicted probabilities in Table 6.

\section{A. Early retirement-farm transfer model}

The likelihood of transferring the farm to next generation is higher than the likelihood of closing down the farm on those farms choosing the farmers' early retirement pension. The estimated correlation coefficient $(\rho=0.989)$ is positive and significantly different from zero at the $1 \%$ or smaller level, indicating that there is a dependency between these two decisions. This implies that the two successive decisions are to be estimated jointly. 
Most of the parameter estimates for the early retirement and farm transfer model reported in Table 5 are significantly different from zero at the less than 5\% level of significance. The forest area and share of barley subsidy of agricultural income are insignificant at less than $10 \%$ level when modelling the choice of the farmers' early retirement system and interaction of northern location and forest area when modelling farm transfer.

Among other most significant factors influencing probability of choosing the farmer's early retirement pension is the age of the spouse. Contradicting separate probit models, an increase in farmers' ages decreases and an increase in spouses' ages increases the probability of transferring the farm to a new entrant when choosing the farmers' early retirement pension. Likewise, the bivariate results suggest that livestock farms are less likely transferred to a new entrant contradicting earlier results based on separate probit models.

In addition, off-farm income decreases farm transfer probability. This again contradicts the results obtained by separate probit models. Choosing farmers' early retirement pension increases the farm transfer probability and it is strongly significant at the less than $1 \%$ level of significance.

\section{B. Non-early retirement - continued farming model}

The likelihood of continuing to farm is higher than the likelihood to choose an old-age or other form of pension concerning farms not choosing the farmers' early retirement pension. The estimated correlation coefficient $(\rho=0.419)$ is positive but not significantly different from zero at $10 \%$ or higher level of significance, interpreted as there being no significant dependency between these two decisions and that they can be estimated independently. Although, due to the nature of the decision processes, a joint estimation is still feasible, it does not enhance the efficiency of the estimates.

Most of the parameter estimates for not choosing the early retirement system are statistically significant at the less than $10 \%$ level. The only exceptions are the farmer's age, the forest area and share of barley subsidy of agricultural income. From the parameter estimates for continuing to farm, the number of children, the age of the oldest child, the agricultural and forest area, the share of barley subsidy of agricultural income and the interaction terms for agricultural land in the South, and the forest area in the North are insignificant at any reasonable levels of significance.

Among the most significant parameter estimates for not choosing the farmers' early retirement system is the age of the spouse and for continuing to farm, the age of the farmer, which corresponds to the results of the separate probit models. Signs for the estimated parameters for not choosing the farmers' early retirement pension are naturally opposite to those estimated in first probit model for choosing farmers' early retirement pension (Model 1 on Table 3).

Contrary to the separate probit model estimated earlier (Model 3 in Table 3), an increasing number of children and agricultural area decreases the probability of continu- 
ing to farm when a farmer does not choose the farmers' early retirement system. This might be the case because farmers prefer successions rather than other early retirement schemes. Otherwise, the bivariate parameter estimates for continuing to farm (Table 5) have the same signs as those estimated by univariate probit model (Model 3 on Table $3)$.

In summary, the results presented above suggest that the decision of not choosing the farmers' early retirement pension increases the probability of continuing to farm and is highly significant at the less than $1 \%$ level.

Table 5.

Table 6.

\section{SUMMARY AND CONCLUSIONS}

This paper analyses the effects of farm and farm family characteristics, economic incentives and off-farm income on farming couple's retirement decisions and their choices of pension system. The existing pension systems available are broadly divided into farmers' early retirement system and to all other forms of normal retirement. In addition to the choice of early retirement, the farming couple may continue farming.

The choice of the farmers' early retirement system is further divided into farm transfers to a new entrant and farm closures. This study is distinguished from earlier similar studies by focusing on farms as units, rather than on farmers, as is the case in many earlier studies. This is partly because of the restrictions involved with farmers' early retirement systems, according to which when one of the farming couple retires a decision to transfer or close down the farm concerns all the farming activities. And on the contrary, according to the schemes one of the spouses may continue farming, although the other one retires involuntarily or by means of other pension schemes. The analysis presented here is based on univariate probit and bivariate probit models.

When comparing farms which chose the farmers' early retirement pension with those which did not, we find that in the former case farmers and spouses are slightly older, operate the farm jointly and they have more and older children than the latter case. The farms run by those choosing the early retirement pension also are to some extent larger than other farms in the sample measured by the size of arable land and forest area. Among other characteristics of farms choosing the early retirement system, we notice that they are also more often located in southern parts of the country and are less likely livestock farms. Because of having a relatively higher agricultural income than other farms, also the income loss is more pronounced. These farms also have smaller offfarm income than other farms in the sample.

The results in general support the earlier findings that after first increasing, the probability of retiring by means of the farmers' early retirement scheme decreases according to the farmer's age. However, farmers' early retirement is an increasing function of the age of the spouse. Also, the bigger the farm and the longer farmer has been farm- 
ing, the more likely early retirement is. Choosing the farmers' early retirement system is more likely in southern parts of the country and on non-livestock farms. The increase in both farm and off-farm income decreases the early retirement probability as well.

Once a farmer has chosen the farmers' early retirement system, the larger the farm, the higher is the likelihood that the farm is transferred and less likely closed down. The farm transfer is more likely also on those farms having more children and an increasing function of the age of the oldest child. Both these findings are consistent with earlier results. Farm closure is more likely in the northern parts of the country and the smaller the farm income is. Also, the share of barley subsidy of farm income increases the probability of farm closure and decreases the probability of farm transfer.

Among those farming couples not choosing the farmers' early retirement pension, the older the farming couple and the longer the farmer has been farming the more likely they will choose some other pension scheme. Also, the existence of a possible successor at an optimal age increases their retirement probability. In northern parts of the country, farmers are also less likely to continue farming.

The results of bivariate probit models where two successive decisions are jointly estimated suggest that the choice of the farmers' early retirement system and the transfer of farm to a new entrant are dependent of each other, but there is no dependency between not choosing the farmers' early retirement pension and the continuation of farming. Choosing the farmers' early retirement system also increases the farm transfer probability and not choosing farmers' early retirement pension increases the probability of continuing to farm.

Unlike the results obtained from univariate models, an increasing farmer's age decreases transfer probability, while an increasing spouse's age increases the transfer probability when choosing the farmers' early retirement pension. In addition, nonlivestock farms are more likely transferred to a new entrant when an early retirement pension is chosen.

Also, the effect of off-farm income differs between univariate probit and bivariate probit model results. The univariate probit model's results suggest that off-farm income decreases the probability of choosing the farmers' early retirement system but increases the probability of farm transfer. The bivariate probit models results indicate that off-farm income decreases both probability of choosing the early retirement pension and of transferring the farm to a new entrant. The latter result is in accordance with earlier studies suggesting that off-farm income and part-time farming accelerate farm exits.

One reason for the difference between univariate and bivariate probit results is the way of constructing the model. In the univariate probit models for choosing early retirement and transferring the farm to a new entrant, both these choices are modelled separately being unconditional of each other which is not the case in the bivariate model. Also, a dummy variable indicating choice of early retirement is not included in the univariate probit model as an independent variable, whereas in the bivariate model the 
choice variable is found to be highly significant in explaining farm transfer probability. The number of observations is also different. In the univariate probit model for farm transfer, the observations included in to the analysis are those choosing the farmers' early retirement scheme, whereas in the bivariate model for choosing the early retirement scheme and the farm transfer, all observations in the data set are included in the analysis. The model performance also clearly indicates that these two decisions are to be estimated jointly rather than separately.

In summary, the study results in the identification of important factors in the decision of choosing to retire early and the subsequent decision regarding the transfer or the cessation farm operations. Despite some variations in significance and effects of each factor, the ages of the farmer, the spouse and the oldest child, the number of potential successors, farm size, the location of the farm, off-farm earnings and crop subsidy together with income loss are found to be the most important determinants of the early retirement and transfer or closure of farms.

The authors would like to thank Pentti Saarimäki from the Finnish Farmers' Social Insurance Institution (Mela) for providing the data and Kyösti Pietola from Agrifood Research Finland for his valuable comments and suggestions on an earlier version of this paper. Generous funding from the Ministry of Agriculture and Forestry, Finland, and Mela is gratefully acknowledged.

1) Recently new methods have been developed to study a sequence of decisions made using multilevel probit models (e.g. Renard et al. 2004). In comparison with a traditional unilevel probit model, the multilevel model has the advantage that it accounts for the interrelationship between the sequences of decisions by conditioning on earlier stages. However, in the latter case, gains are achieved at the cost of complexity of the model structure, estimation procedures, diagnosis and, not least, interpretation of the results. We find the use of bivariate probit model sufficient method of analysis of early retirement here.

2) These results are not reported here due to limitations of space. Results not reported here can, however, be obtained from the authors upon request. 


\section{REFERENCES}

Blanc M, Perrier-Cornet P (1993) Farm transfer and farm entry in the European Community. Sociologia Ruralis 33: 319-335.

Errington A, Lobley M (2002) Handing Over the Reins: A Comparative Study of Intergenerational Farm Transfer in England, France, Canada and the USA. Contributed paper presented in EAAE $10^{\text {th }}$ Congress in Zaragoza. CD-Rom: Exploring the Diversity in the European Agri-Food System, EAAE.

Gasson R, Crow G, Errington A, Hutson J, Marsden T, Winter DM (1988) The Farm as a Family Business: A Review. Journal of Agricultural Economics 39: 1-41.

Glauben T, Tietje H, Weiss CR (2002) Intergenerational Succession on Family Farms: Evidence from Survey Data. Contributed paper presented in EAAE $10^{\text {th }}$ Congress in Zaragoza, in August 2002. Article in CD-Rom. Exploring the Diversity in the European Agri-Food System, EAAE.

Goetz SJ, Debertin DL (2001) Why farmers quit: A county-level analysis. American Journal of Agricultural Economics 83: 1010-1023.

Greene WH (1998) Gender Economic Courses in Liberal Arts Colleges: Further Results. Journal of Economic Education Vol. 29, 4: 291-300.

Hakola T (2003) Alternative Approaches to Model Withdrawals from the Labour Market. A Literature Review. Working Paper 2003: 4. Department of Economics. Uppsala University.

HE 1992:194. Government's proposal to parliament for the law for farm closure compensation (in Finnish).

HE 1994:162. Government's proposal to parliament for the law for farmers' early retirement aid (in Finnish).

HE 1999:131. Government's proposal to parliament for changing the law for farmers' early retirement aid (in Finnish).

Hennessy T (2002) Modelling Succession on Irish Dairy Farms. Contributed paper presented in EAAE $10^{\text {th }}$ Congress in Zaragoza, in August 2002. Article in CDRom. Exploring the Diversity in the European Agri-Food System, EAAE.

Kerkhofs M, Lindeboom M, Theeuwes J (1999) Retirement, financial incentives and health. Labour Economics 6: 203-227.

Kimhi A (1994) Optimal Timing of Farm Transferal From Parent to Child. American Journal of Agricultural Economics 76: 228-236.

Kimhi A (2000) Is Part-Time Farming Really a Step in the Way Out of Agriculture? American Journal of Agricultural Economics 82: 38-48.

Kimhi A, Bollman R (1999) Family farm dynamics in Canada and Israel: the case of farm exits. Agricultural Economics 22: 69-79.

Kimhi A, Nachlieli N (2001) Intergenerational Succession on Israeli Family Farms. Journal of Agricultural Economics 52: 42-58. 
Maddala GS (1983) Limited-dependent and qualitative variables in econometrics. Econometric Society Monographs No. 3. Cambridge University Press. USA.

Mela (2003) Brochures for Farmers' Early Retirement Aid. Farmers' Social Insurance Institution. Espoo.

Mela (2004) Statistics of Farmers' Social Insurance Institution (Mela). Web-pages: www.mela.fi. Referred to: 6.7.2004.

Mishra AK, Goodwin BK (1997) Farm Income Variability and the Supply of Off-farm Labor. American Journal of Agricultural Economics 79: 880-887.

Pfeffer M (1989) Part-time farming and the stability of family farms in the Federal Republic of Germany. European Review of Agricultural Economics 16: 425444.

Pietola K, Väre M, Oude Lansink A (2003) Timing and type of exit from farming: farmers' early retirement programmes in Finland. European Review of Agricultural Economics 30: 99-116.

Potter C, Lobley M (1992) Ageing and succession on family farms. The Impact on Decision-making and Land Use. Sociologia Ruralis 32: 317-334.

Renard D, Molenberghs G, Geys H (2004) A pairwise likelihood approach to estimation in multilevel probit models. Computational Statistics \& Data Analysis 44: 649-667.

Statistics Finland (2000) Income and Tax Statistics of Agriculture and Forestry. Helsinki. 87 p. And earlier publications.

Stiglbauer A, Weiss CR (2000) Family and Non-Family Succession in the UpperAustrian Farm Sector, Cahiers d'Économie et Sociologie Rurales 54: 6-26.

Weiss CR (1999) Farm Growth and Survival: Econometric Evidence for Individual Farms in Upper Austria. American Journal of Agricultural Economics 81: 103116. 
Table 1. Summary statistics of the Mela pension data, 1993-1998.

\begin{tabular}{|c|c|c|c|c|c|}
\hline Variable & Definition & Mean & Std. Dev. & Min. & Max. \\
\hline \multicolumn{6}{|c|}{ Part A. Early retirement pension, $\mathrm{NT}=5,778^{\mathrm{a}}$} \\
\hline Fage & Farmer's age, years & 58.9 & 4.5 & 43.0 & 77.0 \\
\hline Sage & Spouse's age, years & 53.9 & 5.2 & 32.0 & 68.0 \\
\hline Spouse & Spouse $(0.1)$ & 0.47 & 0.5 & 0.0 & 1.0 \\
\hline Ffarmage & Farming years of farmer & 28.6 & 10.2 & 1.0 & 59.0 \\
\hline Children & Number of children & 2.3 & 1.7 & 0.0 & 17.0 \\
\hline Childage & Age of the oldest child, years & 25.7 & 13.3 & 0.0 & 49.0 \\
\hline Land & Arable land area, ha & 15.4 & 14.4 & 0.0 & 118.0 \\
\hline Forest & Forest area, ha & 51.2 & 63.1 & 0.0 & 856.0 \\
\hline Livestock & Livestock and dairy farm $(0.1)$ & 0.33 & 0.5 & 0.0 & 1.0 \\
\hline North & North $(0.1)$ & 0.13 & 0.3 & 0.0 & 1.0 \\
\hline Trend & Trend $(1993=1)$ & 3.5 & 1.7 & 1.0 & 6.0 \\
\hline Xreplace & Income loss of early retire., euro ${ }^{b}$ & $2,748.6$ & $8,064.7$ & 0.0 & $109,353.0$ \\
\hline Xagrincome & Agricultural income, euro & $7,185.1$ & $12,229.3$ & 0.0 & $127,365.0$ \\
\hline Xoffincome & Off-farm income, euro & $3,105.5$ & $8,247.1$ & 0.0 & $111,424.0$ \\
\hline Sshare & Share of subsidy ${ }^{\mathrm{c}}$ & 0.9 & 14.6 & 0.0 & 962.4 \\
\hline \multicolumn{6}{|c|}{ Part B. Farm transfer, NT=1,164 } \\
\hline Fage & Farmer's age, years & 59.4 & 3.9 & 50.0 & 70.0 \\
\hline Sage & Spouse's age, years & 55.8 & 3.9 & 43.0 & 66.0 \\
\hline Spouse & Spouse $(0.1)$ & 0.71 & 0.46 & 0.0 & 1.0 \\
\hline Ffarmage & Farming years of farmer & 30.5 & 8.4 & 4.0 & 53.0 \\
\hline Children & Number of children & 2.6 & 1.9 & 0.0 & 17.0 \\
\hline Childage & Age of the oldest child, years & 29.1 & 11.1 & 0.0 & 47.0 \\
\hline Land & Arable land area, ha & 21.3 & 14.3 & 0.0 & 97.0 \\
\hline Forest & Forest area, ha & 52.5 & 48.8 & 1.0 & 338.0 \\
\hline Livestock & Livestock and dairy farm $(0.1)$ & 0.28 & 0.45 & 0.0 & 1.0 \\
\hline North & North $(0.1)$ & 0.09 & 0.29 & 0.0 & 1.0 \\
\hline Trend & Trend $(1993=1)$ & 3.5 & 1.7 & 1.0 & 6.0 \\
\hline Xreplace & Income loss of early retire, euro ${ }^{b}$ & $3,789.1$ & $11,260.8$ & 0.0 & $109,353.0$ \\
\hline Xagrincome & Agricultural income, euro & $8,591.9$ & $15,795.1$ & 0.0 & $127,365.0$ \\
\hline Xoffincome & Off-farm income, euro & $1,372.1$ & $5,410.9$ & 0.0 & $48,648.0$ \\
\hline Sshare & Share of subsidy ${ }^{\mathrm{c}}$ & 0.3 & 2.2 & 0.0 & 60.3 \\
\hline \multicolumn{6}{|c|}{ Part C. Continue farming, NT $=4,614$} \\
\hline Fage & Farmer's age, years & 58.9 & 4.7 & 43.0 & 77.0 \\
\hline Sage & Spouse's age, years & 53.1 & 5.4 & 32.0 & 68.0 \\
\hline Spouse & Spouse $(0.1)$ & 0.42 & 0.49 & 0.0 & 1.0 \\
\hline Ffarmage & Farming years of farmer & 28.1 & 10.6 & 1.0 & 59.0 \\
\hline Children & Number of children & 2.2 & 1.7 & 0.0 & 12.0 \\
\hline Childage & Age of the oldest child, years & 24.9 & 13.7 & 0.0 & 59.0 \\
\hline Land & Arable land area, ha & 13.9 & 14.0 & 0.0 & 118.0 \\
\hline Forest & Forest area, ha & 50.9 & 66.2 & 0.0 & 856.0 \\
\hline Livestock & Livestock and dairy farm $(0.1)$ & 0.35 & 0.48 & 0.0 & 1.0 \\
\hline North & North $(0.1)$ & 0.14 & 0.34 & 0.0 & 1.0 \\
\hline
\end{tabular}


Trend

Xreplace

Xagrincome

Xoffincome

Trend $(1993=1)$

Income loss of early retire., euro ${ }^{b}$

Agricultural income, euro

Off-farm income, euro

Share of subsidy ${ }^{\mathrm{c}}$
3.5

$2,486.1$

1.7

$6,831.2$

$7,009.9$

1.0

6.0

Sshare

$11,125.1$

$\begin{array}{ll}0.0 & 87,307.0\end{array}$

$3,542.8$

$8,766.2$

$95,838.0$

a) The number of farms, periods and observations is 963,6 and 5,778, respectively.

b) Agricultural income minus expected early retirement pension (per farm).

c) (Subsidy for barley per hectare * land size)/agricultural income per farm. 
Table 2. Correlation matrix, NT=5,778 observations.

\begin{tabular}{|c|c|c|c|c|c|c|c|c|c|c|c|}
\hline & \multicolumn{8}{|c|}{ Independent variables } & \multicolumn{3}{|c|}{$\begin{array}{l}\text { Dependent } \\
\text { variables }\end{array}$} \\
\hline & Fage & Sage & Children & Land & Forest & $\begin{array}{l}\text { Xre- } \\
\text { place }\end{array}$ & $\begin{array}{l}\text { Xagri- } \\
\text { income }\end{array}$ & $\begin{array}{c}\text { Xoff- } \\
\text { income }\end{array}$ & Sshare & $\begin{array}{l}\text { Xpen- } \\
\text { sion }\end{array}$ & Xtrans. \\
\hline Sage & $0.009 \mathrm{~d}$ & & & & & & & & & & \\
\hline Children & $0.019 \mathrm{~d}$ & $0.129 \mathrm{a}$ & & & & & & & & & \\
\hline Land & $-0.065 \mathrm{a}$ & $0.237 \mathrm{a}$ & $0.053 \mathrm{a}$ & & & & & & & & \\
\hline Forest & $0.003 \mathrm{~d}$ & $0.029 b$ & $0.089 \mathrm{a}$ & $0.030 \mathrm{~b}$ & & & & & & & \\
\hline Xreplace & $-0.104 a$ & $-0.015 a$ & $0.059 \mathrm{a}$ & $0.303 \mathrm{a}$ & $0.039 \mathrm{a}$ & & & & & & \\
\hline Xagrincome & $-0.145 a$ & $0.259 \mathrm{a}$ & $0.092 \mathrm{a}$ & $0.447 \mathrm{a}$ & $0.068 \mathrm{a}$ & $0.944 \mathrm{a}$ & & & & & \\
\hline Xoffincome & $-0.258 \mathrm{a}$ & $0.056 \mathrm{a}$ & $0.021 \mathrm{~d}$ & $0.016 \mathrm{~d}$ & $-0.070 \mathrm{a}$ & $0.029 \mathrm{a}$ & $0.037 \mathrm{a}$ & & & & \\
\hline Sshare & $-0.004 \mathrm{~d}$ & $0.006 \mathrm{~d}$ & $-0.001 \mathrm{~d}$ & $0.022 \mathrm{~d}$ & $-0.015 d$ & $-0.022 \mathrm{~d}$ & $-0.025 d$ & $0.022 \mathrm{~d}$ & & & \\
\hline Xpension & $0.041 \mathrm{a}$ & $0.256 a$ & $0.085 \mathrm{a}$ & $0.207 \mathrm{a}$ & $0.010 \mathrm{~d}$ & $-0.044 a$ & $0.058 \mathrm{a}$ & $-0.106 a$ & $-0.019 d$ & & \\
\hline Xtransfer & $0.038 \mathrm{a}$ & $0.180 \mathrm{a}$ & $0.152 \mathrm{a}$ & $0.232 \mathrm{a}$ & $0.049 \mathrm{a}$ & $-0.088 \mathrm{~d}$ & $0.006 \mathrm{~d}$ & $-0.089 a$ & $-0.019 d$ & $0.708 \mathrm{a}$ & \\
\hline Xcontinue & $-0.346 a$ & $0.362 \mathrm{a}$ & $-0.005 \mathrm{~d}$ & $0.062 \mathrm{a}$ & $0.026 \mathrm{c}$ & $0.069 \mathrm{a}$ & $0.167 \mathrm{a}$ & $0.229 \mathrm{a}$ & $0.025 \mathrm{~d}$ & $-0.412 \mathrm{a}$ & $-0.291 \mathrm{a}$ \\
\hline
\end{tabular}

Note: Significant at the less than 1\% (a), $1-5 \%$ (b), $5-10 \%$ (c), and more than $10 \%$ (d) levels insignificant.

Glossary of variables: The choice of early retirement or not (Xpension), the farmer has chosen early retirement and transfers the farm to a new entrant or not (Xtransfer), farmer has not chosen early retirement and either continue farming or chose an old age pension (Xcontinue). 
Table 3. Parameter estimates of estimated three probit models.

\begin{tabular}{|c|c|c|c|}
\hline & $\begin{array}{r}\text { Early retirement } \\
\text { pension }\end{array}$ & Farm transfer & $\begin{array}{r}\text { Continue } \\
\text { farming }\end{array}$ \\
\hline Independent variable & Coefficient & Coefficient & Coefficient \\
\hline Constant & $-0.7439 b$ & $-0.8001 \mathrm{~d}$ & $8.2453 \mathrm{a}$ \\
\hline Fage & $-0.0083 \mathrm{c}$ & $0.0038 \mathrm{~d}$ & $-0.1678 \mathrm{a}$ \\
\hline Sage & $0.0143 \mathrm{a}$ & $-0.0054 \mathrm{a}$ & $-0.1815 \mathrm{a}$ \\
\hline Spouse & - & - & $12.6345 \mathrm{a}$ \\
\hline Ffarmage & $0.0111 \mathrm{a}$ & $0.0004 \mathrm{~d}$ & $-0.0077 \mathrm{a}$ \\
\hline Children & $0.0501 \mathrm{a}$ & $0.1738 \mathrm{a}$ & $0.0067 \mathrm{~d}$ \\
\hline Childage & - & $0.0318 \mathrm{a}$ & $-0.0030 \mathrm{~d}$ \\
\hline Land & $0.0457 \mathrm{a}$ & $0.0257 \mathrm{a}$ & $0.0024 \mathrm{~d}$ \\
\hline Forest & $-0.0007 \mathrm{c}$ & $0.0072 \mathrm{a}$ & $0.0008 \mathrm{~b}$ \\
\hline Livestock & $-0.2239 a$ & $0.0635 \mathrm{~d}$ & $0.0751 \mathrm{~d}$ \\
\hline North & $-0.6254 \mathrm{a}$ & $-0.6902 \mathrm{a}$ & $-0.2588 \mathrm{a}$ \\
\hline Trend & $-0.0777 \mathrm{a}$ & $-0.2119 \mathrm{a}$ & $0.2451 \mathrm{a}$ \\
\hline Xreplace, $\log$ & $0.0296 \mathrm{a}$ & - & - \\
\hline Xagrincome, log & $-0.0709 \mathrm{a}$ & $-0.1362 \mathrm{a}$ & $0.0268 \mathrm{a}$ \\
\hline Xoffincome, log & $-0.0353 \mathrm{a}$ & $0.0305 \mathrm{~b}$ & $0.0169 \mathrm{~b}$ \\
\hline Sshare & $-0.0089 \mathrm{~d}$ & $-0.1852 \mathrm{a}$ & $0.0008 \mathrm{~d}$ \\
\hline Southland & $-0.0299 a$ & - & \\
\hline Northforest & $0.0019 \mathrm{~b}$ & - & - \\
\hline Log-likelihood & $-2,472.087$ & -576.277 & $-1,511.967$ \\
\hline Restricted log-likelihood & $-2,902.932$ & -799.323 & $-3,198.084$ \\
\hline Likelihood ratio test (DF) & 861.689 & 446.091 & $3,372.233$ \\
\hline Degrees of freedom & 15 & 13 & 15 \\
\hline Number of $0 / 1$ observations & $4,614 / 1,164$ & $516 / 648$ & $2,292 / 2322$ \\
\hline Total number of observations & 5,778 & 1,164 & 4,614 \\
\hline
\end{tabular}

Note: Significant at the less than $1 \%$ (a), $1-5 \%$ (b), $5-10 \%$ (c), and more than $10 \%$ (d) levels insignificant. 
Table 4. Predicted (column) and observed (row) probabilities based on the univariate probit models.

\begin{tabular}{|c|c|c|c|c|c|c|}
\hline & \multicolumn{2}{|c|}{0} & \multicolumn{2}{|c|}{1} & \multicolumn{2}{|c|}{ Total } \\
\hline & $\mathrm{N}$ & $\%$ & $\mathrm{~N}$ & $\%$ & $\mathrm{~N}$ & $\%$ \\
\hline \multicolumn{7}{|c|}{ Early retirement pension } \\
\hline 0 & 4,481 & 97.1 & 133 & 37.7 & 4,614 & 79.9 \\
\hline 1 & 942 & 17.4 & 222 & 19.1 & 1,164 & 20.1 \\
\hline Total & 5,423 & 82.6 & 355 & 62.5 & 5,778 & 100.0 \\
\hline \multicolumn{7}{|c|}{ Farm transfer } \\
\hline 0 & 357 & 69.2 & 159 & 23.1 & 516 & 44.3 \\
\hline 1 & 118 & 24.8 & 530 & 81.8 & 648 & 55.7 \\
\hline Total & 475 & 75.2 & 689 & 76.9 & 1164 & 100.0 \\
\hline \multicolumn{7}{|c|}{ Continue farming } \\
\hline 0 & 2,018 & 88.1 & 274 & 13.1 & 2,292 & 49.7 \\
\hline 1 & 505 & 20.0 & 1817 & 78.3 & 2,322 & 50.3 \\
\hline Total & 2,523 & 79.9 & 2,091 & 83.1 & 4,614 & 100.0 \\
\hline
\end{tabular}

Note: Observed column / Predicted row percentages. 
Table 5. Parameter estimates for bivariate probit models.

\begin{tabular}{|c|c|c|c|c|}
\hline & \multicolumn{2}{|c|}{$\begin{array}{l}\text { Early retirement - } \\
\text { farm transfer }\end{array}$} & \multicolumn{2}{|c|}{$\begin{array}{l}\text { No early retirement - } \\
\text { continued farming }\end{array}$} \\
\hline & $\begin{array}{l}\text { Early } \\
\text { retirement }\end{array}$ & Transfer & Non-retired & Continued \\
\hline Constant & $0.1006 \mathrm{~d}$ & - & $0.7631 \mathrm{~b}$ & - \\
\hline Fage /10 & $-0.2330 a$ & $-0.4178 \mathrm{a}$ & $0.0806 \mathrm{~d}$ & $-1.6281 \mathrm{a}$ \\
\hline Sage /10 & $0.1445 \mathrm{a}$ & $0.1006 \mathrm{a}$ & $-0.1437 \mathrm{a}$ & $-1.7572 \mathrm{a}$ \\
\hline Spouse & - & - & - & $12.1041 \mathrm{a}$ \\
\hline Ffarmage /10 & $0.1232 \mathrm{a}$ & $0.1038 \mathrm{a}$ & $-0.1137 \mathrm{a}$ & $-0.0964 \mathrm{a}$ \\
\hline Children & $0.0512 \mathrm{a}$ & $0.1002 \mathrm{a}$ & $-0.0511 \mathrm{a}$ & $-0.0001 \mathrm{~d}$ \\
\hline Childage /10 & - & $0.1767 \mathrm{a}$ & - & $-0.0277 \mathrm{~d}$ \\
\hline Land /10 & $0.4696 \mathrm{a}$ & $0.5002 \mathrm{a}$ & $-0.4585 a$ & $-0.0059 d$ \\
\hline Forest $/ 10$ & $-0.0082 \mathrm{~d}$ & $0.0201 \mathrm{a}$ & $0.0069 \mathrm{~d}$ & $0.0063 \mathrm{~d}$ \\
\hline Livestock & $-0.2358 \mathrm{a}$ & $-0.1672 \mathrm{a}$ & $0.2193 \mathrm{a}$ & $0.1029 \mathrm{c}$ \\
\hline North & $-0.6767 \mathrm{a}$ & $-0.5732 b$ & $0.5932 \mathrm{a}$ & $-0.2462 \mathrm{c}$ \\
\hline Trend & $-0.0713 \mathrm{a}$ & $-0.1379 a$ & $0.0776 \mathrm{a}$ & $0.2487 \mathrm{a}$ \\
\hline Xreplace, log & $0.0132 \mathrm{~b}$ & - & $-0.0305 \mathrm{a}$ & - \\
\hline Xagrincome, log & $-0.0628 \mathrm{a}$ & $-0.1042 a$ & $0.0737 \mathrm{a}$ & $0.0330 \mathrm{a}$ \\
\hline Xoffincome, log & $-0.0403 \mathrm{a}$ & $-0.0286 a$ & $0.0348 \mathrm{a}$ & $0.0209 \mathrm{~b}$ \\
\hline Sshare & $-0.1079 d$ & $-1.066 \mathrm{a}$ & $0.0852 \mathrm{~d}$ & $0.0125 \mathrm{~d}$ \\
\hline Southland & $-0.3102 \mathrm{a}$ & $-0.2775 b$ & $0.3019 \mathrm{a}$ & $0.0029 \mathrm{~d}$ \\
\hline Northforest & $0.0213 \mathrm{~b}$ & $0.0019 \mathrm{~d}$ & $-0.0163 \mathrm{c}$ & $0.0022 \mathrm{~d}$ \\
\hline Early retirement pension & - & $0.4785 \mathrm{a}$ & - & - \\
\hline No early retirement pension & - & - & - & $7.9039 \mathrm{a}$ \\
\hline Disturbance correlation & & $0.9898 \mathrm{a}$ & & $0.4189 \mathrm{~d}$ \\
\hline \multicolumn{5}{|l|}{ Model performance: } \\
\hline Log-likelihood & & $-3,069.581$ & & $-3,981.606$ \\
\hline Number of $0 / 1$ observations & $4,614 / 1,164$ & $516 / 648$ & $1,164 / 4,614$ & $2,292 / 2,322$ \\
\hline Total number of observations & 5,778 & 1,164 & 5,778 & 4,614 \\
\hline
\end{tabular}

Note: $\quad$ Significant at the less than 1\% (a), 1-5\% (b), 5-10\% (c), and more than $10 \%$ (d) levels insignificant. 
Table 6. Predicted and observed probabilities based on bivariate probit models.

\begin{tabular}{llrrrrrr}
\hline & Model & Farm transfer & & & & \\
\hline Cases & Observations & 0 & $\%$ & 1 & $\%$ & Total & $\%$ \\
\hline No early & Observed & 4,614 & 79.9 & 0 & 0 & 4,614 & 79.9 \\
retirement & Predicted & 5,585 & 96.6 & 0 & 0 & 5,585 & 96.6 \\
pension & & & & & & & \\
& & & & & & & \\
Early & Observed & 516 & 8.9 & 648 & 11.2 & 1,164 & 20.1 \\
retirement & Predicted & 17 & 0.3 & 176 & 3.1 & 193 & 3.4 \\
pension & & & & & & & \\
& & & & & & & \\
Total & Observed & 5,130 & 88.8 & 648 & 11.2 & 5,778 & 100 \\
& Predicted & 5,602 & 96.9 & 176 & 3.1 & 5,778 & 100 \\
& & & & & & & \\
\hline & Model & Continue farming & & & & \\
\hline Cases & Observations & 0 & $\%$ & 1 & $\%$ & Total & $\%$ \\
\hline No early & Observed & 2,292 & 39.7 & 2322 & 40.2 & 4,614 & 79.9 \\
retirement & Predicted & 3,406 & 58.9 & 1994 & 34.5 & 5,400 & 93.4 \\
pension & & & & & & & \\
Early & Observed & 1,164 & 20.1 & 0 & 0 & 1,164 & 20.1 \\
retirement & Predicted & 304 & 5.3 & 74 & 1.3 & 378 & 6.6 \\
pension & & & & & & & \\
Total & Observed & 3,456 & 59.8 & 2322 & 40.2 & 5,778 & 100 \\
& Predicted & 3,710 & 64.2 & 2069 & 35.8 & 5,778 & 100 \\
& & & & & & & \\
\hline
\end{tabular}




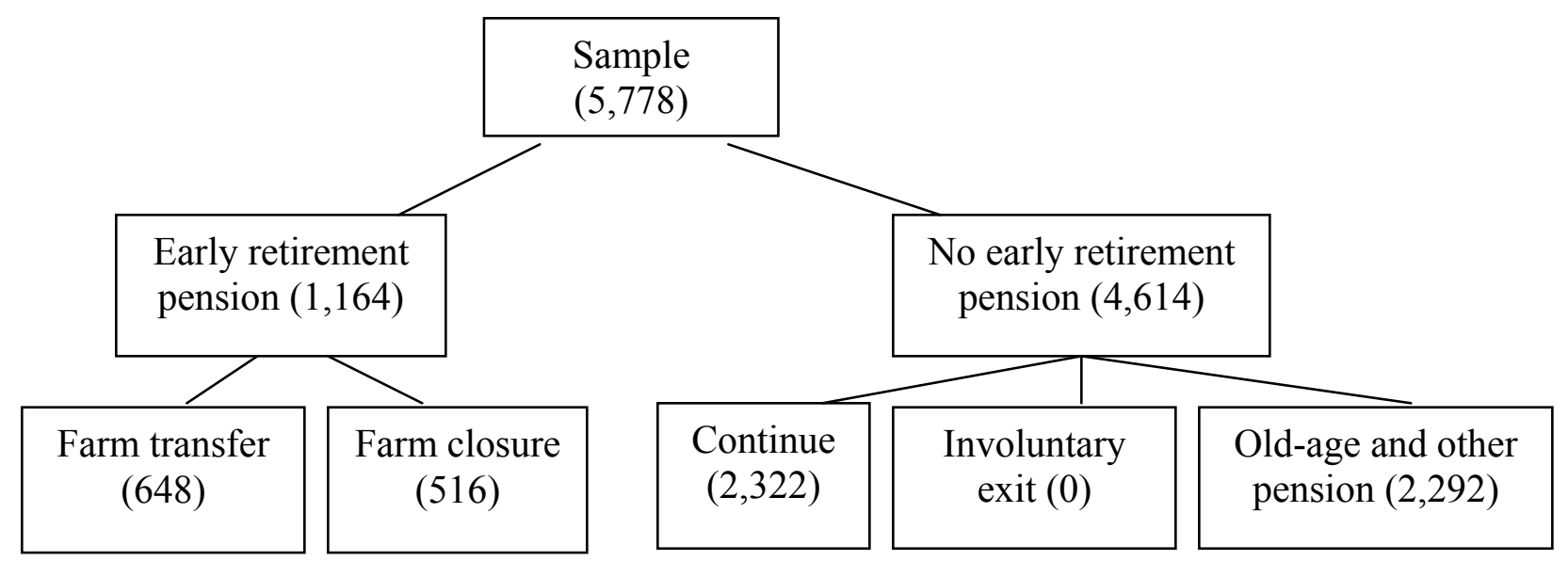

Figure 1. Number of farms according to the choice of pension scheme. 


\section{Appendix 1}

Number of insured farms and farmers ${ }^{\text {a }}$, total field area and average farm size of insured farms and number of farms on which farmers have exited farming after the farmers' early retirement schemes in 1974-2003 (Mela, 2004).

\begin{tabular}{cccccc}
\hline & $\begin{array}{c}\text { Number } \\
\text { of insured } \\
\text { farms }\end{array}$ & $\begin{array}{l}\text { Number } \\
\text { of insured } \\
\text { farmers }\end{array}$ & $\begin{array}{c}\text { Land } \\
\text { million } \\
\text { ha }\end{array}$ & $\begin{array}{c}\text { Average size } \\
\text { ha/farm }\end{array}$ & $\begin{array}{c}\text { Farms involved } \\
\text { in the early } \\
\text { ret. system }\end{array}$ \\
\hline 1974 & 193,231 & 303,761 & 2.06 & 10.7 & 194 \\
1975 & 185,550 & 286,874 & 2.02 & 10.9 & 2,053 \\
1976 & 178,296 & 274,716 & 1.99 & 11.2 & 1,783 \\
1977 & 171,535 & 261,684 & 1.98 & 11.5 & 5,913 \\
1978 & 165,272 & 252,463 & 1.97 & 11.9 & 1,418 \\
1979 & 160,350 & 244,017 & 1.96 & 12.2 & 1,431 \\
1980 & 155,563 & 235,663 & 1.98 & 12.7 & 1,828 \\
1981 & 151,590 & 228,822 & 1.97 & 13.0 & 1,830 \\
1982 & 146,461 & 221,287 & 1.96 & 13.4 & 1,881 \\
1983 & 142,276 & 215,158 & 1.95 & 13.7 & 2,170 \\
1984 & 139,615 & 210,402 & 1.97 & 14.1 & 1,946 \\
1985 & 135,436 & 203,843 & 1.95 & 14.4 & 2,387 \\
1986 & 129,865 & 195,278 & 1.93 & 16.0 & 2,438 \\
1987 & 125,262 & 188,483 & 1.93 & 16.7 & 7,523 \\
1988 & 120,986 & 181,752 & 1.91 & 16.9 & 4,940 \\
1989 & 117,296 & 175,970 & 1.90 & 17.3 & 2,728 \\
1990 & 113,109 & 169,894 & 1.92 & 17.7 & 2,507 \\
1991 & 108,649 & 164,285 & 1.94 & 18.9 & 2,681 \\
1992 & 105,581 & 159,007 & 1.90 & 29.2 & 4,941 \\
1993 & 102,218 & 153,358 & 1.86 & 19.6 & 3,586 \\
1994 & 96,205 & 143,816 & 1.84 & 20.2 & 1,379 \\
1995 & 91,374 & 135,624 & 1.80 & 20.8 & 1,211 \\
1996 & 86,090 & 126,475 & 1.77 & 21.7 & 1,309 \\
1997 & 82,175 & 120,372 & 1.78 & 22.8 & 1,086 \\
1998 & 78,172 & 114,205 & 1.79 & 24.2 & 1,111 \\
1999 & 73,862 & 107,097 & 1.79 & 25.6 & 1,761 \\
2000 & 70,326 & 102,244 & 1.80 & 27.0 & 817 \\
2001 & 67,826 & 98,478 & 1.82 & 28.2 & 745 \\
2002 & 65,746 & 95,158 & 1.86 & 29.6 & 808 \\
2003 & 63,179 & 91,191 & 1.86 & 31.0 & 604 \\
\hline & & & & & \\
\hline
\end{tabular}

a Purchasing pension insurance from the Farmers' Social Insurance Institution (Mela) is in practice obligatory for all farmers. It is also a pre-condition for applying a farmer's early retirement pension after the scheme. 


\section{Appendix 2}

Development of number of insured farms (V1) and farmers (V2), total field area million ha (V3) and average farm size (V4) of insured farms and number of farms on which farmers have exited farming after the farmers' early retirement schemes (V5) in 1974-2003 as an index. Base year is 1974, except for the V5 base year is 1975 . Base year is normalised to 100 . V1 is 193,231 in 1974, V2 is 303,761 in 1974, V3 is 2.06 in 1974, V4 is 10.7 in 1974 and V5 is 2,053 in 1975 (Mela, 2004).

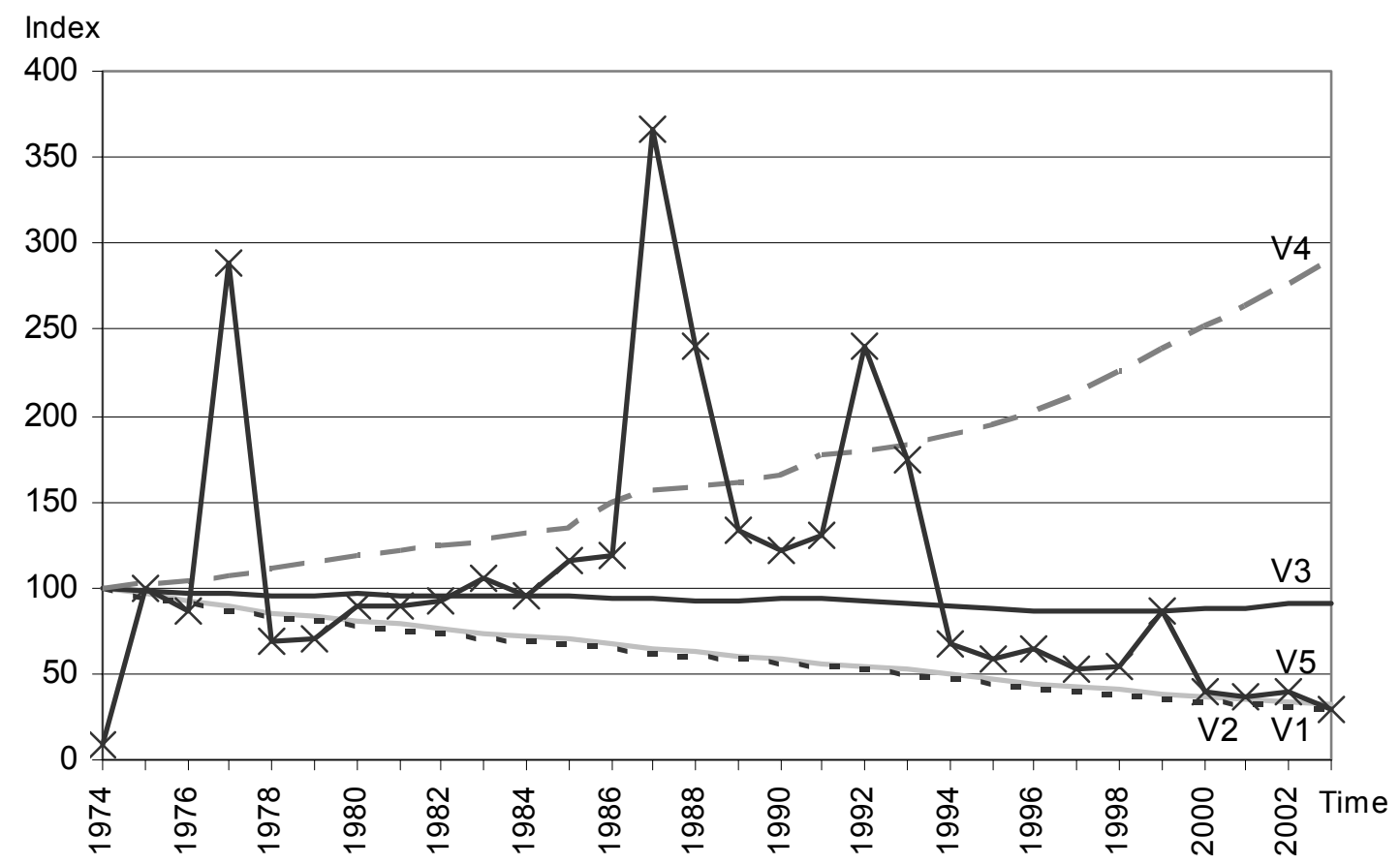

